\title{
Atmospheric protein chemistry influenced by anthropogenic air pollutants: nitration and oligomerization upon exposure to ozone and nitrogen dioxide $\uparrow$
}

\author{
Fobang Liu, ${ }^{a}$ Pascale S. J. Lakey, ${ }^{a}$ Thomas Berkemeier, ${ }^{\text {ab }}$ \\ Haijie Tong, (D) a Anna Theresa Kunert, ${ }^{2}$ Hannah Meusel, ${ }^{a}$ \\ Yafang Cheng, ${ }^{a}$ Hang Su, ${ }^{a}$ Janine Fröhlich-Nowoisky, ${ }^{a}$ Senchao Lai, ${ }^{c}$ \\ Michael G. Weller, ${ }^{d}$ Manabu Shiraiwa, ${ }^{e}$ Ulrich Pöschla \\ and Christopher J. Kampf (D) *af
}

Received 5th January 2017, Accepted 10th March 2017

DOI: $10.1039 / \mathrm{c} 7 \mathrm{fd} 00005 \mathrm{~g}$

The allergenic potential of airborne proteins may be enhanced via post-translational modification induced by air pollutants like ozone $\left(\mathrm{O}_{3}\right)$ and nitrogen dioxide $\left(\mathrm{NO}_{2}\right)$. The molecular mechanisms and kinetics of the chemical modifications that enhance the allergenicity of proteins, however, are still not fully understood. Here, protein tyrosine nitration and oligomerization upon simultaneous exposure of $\mathrm{O}_{3}$ and $\mathrm{NO}_{2}$ were studied in coated-wall flow-tube and bulk solution experiments under varying atmospherically relevant conditions (5-200 ppb $\left.\mathrm{O}_{3}, 5-200 \mathrm{ppb} \mathrm{NO}_{2}, 45-96 \% \mathrm{RH}\right)$, using bovine serum albumin as a model protein. Generally, more tyrosine residues were found to react via the nitration pathway than via the oligomerization pathway. Depending on reaction conditions, oligomer mass fractions and nitration degrees were in the ranges of 2.5$25 \%$ and $0.5-7 \%$, respectively. The experimental results were well reproduced by the kinetic multilayer model of aerosol surface and bulk chemistry (KM-SUB). The extent of nitration and oligomerization strongly depends on relative humidity $(\mathrm{RH})$ due to moisture-induced phase transition of proteins, highlighting the importance of cloud

\footnotetext{
${ }^{a}$ Multiphase Chemistry Department, Max Planck Institute for Chemistry, Hahn-Meitner-Weg 1, 55128 Mainz, Germany

${ }^{b}$ School of Chemical \& Biomolecular Engineering, Georgia Tech, Atlanta, GA, USA

'School of Environment and Energy, South China University of Technology, Higher Education Mega Center, Guangzhou 510006, P. R. China

${ }^{d}$ Division 1.5 Protein Analysis, Federal Institute for Materials Research and Testing (BAM), Richard-WillstätterStr. 11, 12489 Berlin, Germany

${ }^{e}$ Department of Chemistry, University of California, Irvine, CA, USA

${ }^{f}$ Institute for Organic Chemistry, Johannes Gutenberg University Mainz, Duesbergweg 10-14, 55128 Mainz, Germany.E-mail: kampfc@uni-mainz.de

$\dagger$ Electronic supplementary information (ESI) available: Chemical mechanism and corresponding parameters used in kinetic modelling (Table S1), schematic experimental setup (Fig. S1), and SEC calibration curve (Fig. S2). See DOI: 10.1039/c7fd00005g
} 
processing conditions for accelerated protein chemistry. Dimeric and nitrated species were major products in the liquid phase, while protein oligomerization was observed to a greater extent for the solid and semi-solid phase states of proteins. Our results show that the rate of both processes was sensitive towards ambient ozone concentration, but rather insensitive towards different $\mathrm{NO}_{2}$ levels. An increase of tropospheric ozone concentrations in the Anthropocene may thus promote pro-allergic protein modifications and contribute to the observed increase of allergies over the past decades.

\section{Introduction}

Allergies represent an important issue for human health and the prevalence of allergic diseases has been increasing worldwide over the past decades. ${ }^{1,2}$ Among other explanations, air pollution has been proposed as a potential driver for this increase. $^{3-6}$ It is well established that air pollutants, especially diesel exhaust particles (DEPs), can act as adjuvants and facilitate allergic sensitization in the human body., ${ }^{7,8}$ Air pollutants like nitrogen dioxide $\left(\mathrm{NO}_{2}\right)$, sulfur dioxide $\left(\mathrm{SO}_{2}\right)$, and ozone $\left(\mathrm{O}_{3}\right)$ have been shown to interact with and modify allergen carriers like pollen grains and fungal spores, increasing the release of allergenic proteins. ${ }^{\mathbf{8}, \mathbf{9}}$ Moreover, post-translational modifications (PTM) of allergenic proteins can be induced by reactive trace gases such as $\mathrm{O}_{3}$ and $\mathrm{NO}_{2}$ which modifies their structure and activity, thus altering the immunogenicity of the proteins. ${ }^{\mathbf{1 0 - 1 3}}$

Airborne allergenic proteins (aeroallergens) are contained not only in coarse biological particles such as pollen grains, ${ }^{\mathbf{1 4}}$ but also in the fine fraction of air particulate matter (aerodynamic diameter $<2.5 \mu \mathrm{m}$ ). ${ }^{15-17}$ The occurrence of allergenic proteins in fine particles can be explained by several processes, including the release of pollen cytoplasmic granules (PCGs) from the rupture of pollen grains, ${ }^{9}$ fragmentation of airborne cellular material, ${ }^{\mathbf{1 8}}$ and contact transfer of allergenic proteins onto fine particles. ${ }^{18,19}$ Therefore, aeroallergens can be directly exposed to ambient $\mathrm{O}_{3}$ and $\mathrm{NO}_{2}$, promoting chemical modifications like tyrosine (Tyr) nitration and oligomerization.

Laboratory and field investigations have shown that proteins can be oxidized, nitrated and/or oligomerized upon exposure to $\mathrm{NO}_{2}$ and $\mathrm{O}_{3}$ in synthetic gas mixtures or polluted urban air. ${ }^{\mathbf{1 1 , 1 2 , 1 5 , 2 0}}$ The mechanisms of protein nitration by $\mathrm{O}_{3}$ and $\mathrm{NO}_{2}$, and protein cross-linking (oligomerization) by $\mathrm{O}_{3}$ both involve the formation of long-lived reactive oxygen intermediates (ROIs), which are most likely tyrosyl radicals, as proposed earlier. ${ }^{12,20-24}$ The ROIs can subsequently react with each other forming dityrosine (DTyr) crosslinks with $\mathrm{NO}_{2}$ to form nitrotyrosine (NTyr) residues, or undergo further oxidation reactions. Using quantum chemical methods, Sandhiya et al. ${ }^{22}$ showed that six different intermediates can be formed through the initial oxidation of Tyr residues by $\mathrm{O}_{3}$, out of which the tyrosyl radical is favorable due to a small energy barrier, particularly in the aqueous phase. In the absence of $\mathrm{NO}_{2}$, tyrosyl radicals can undergo self-reaction to stabilize in the form of dimers. Under physiological conditions, Pfeiffer et al. ${ }^{25}$ found that DTyr was a major product of Tyr modification caused by low steadystate concentrations of peroxynitrite, while high fluxes $\left(>2 \mu \mathrm{M} \mathrm{s}^{-1}\right)$ of nitrogen oxide/superoxide anions $\left(\mathrm{NO} / \mathrm{O}_{2}{ }^{-}\right)$are required to render peroxynitrite an efficient trigger of Tyr nitration. Thus, kinetic competition between Tyr nitration and dimerization (or oligomerization) upon protein exposure to $\mathrm{O}_{3}$ and $\mathrm{NO}_{2}$ can be 
expected, which needs to be explored in detail to assess the relevant atmospheric conditions that favor potentially health relevant protein modifications.

In this study, we explored the oxidation, nitration, and oligomerization reactions of proteins induced by $\mathrm{O}_{3}$ and $\mathrm{NO}_{2}$, and their kinetics under different atmospherically relevant conditions using bovine serum albumin (BSA) as a model protein. Coated-wall flow-tube and bulk solution experiments were performed to study the kinetics of protein nitration and oligomerization at $\mathrm{O}_{3}$ and $\mathrm{NO}_{2}$ concentrations of 5-200 ppb, and relative humidities (RH) of $45 \%$ and $96 \%$, utilizing a size exclusion chromatography/spectrophotometry method. Additionally, we used the kinetic multilayer model of aerosol surface and bulk chemistry $(\mathrm{KM}-\mathrm{SUB})^{26}$ to investigate which chemical reactions and transport processes control the concentration and time dependence of protein oligomerization and nitration.

\section{Experimental}

\subsection{Materials}

Bovine serum albumin (BSA, A5611) and sodium phosphate monobasic monohydrate $\left(\mathrm{NaH}_{2} \mathrm{PO}_{4} \cdot \mathrm{H}_{2} \mathrm{O}, 71504\right)$, were purchased from Sigma Aldrich (Germany). Sodium hydroxide ( $\mathrm{NaOH}, 0583)$ was purchased from VWR (Germany). 10× Tris/ glycine/SDS (161-0732) was purchased from Bio-Rad Laboratories (USA). High purity water $(18.2 \mathrm{M} \Omega \mathrm{cm}$ ) for chromatography was taken from a Milli-Q Integral 3 water purification system (Merck Millipore, USA). The high purity water (18.2 M $\Omega$ $\mathrm{cm}$ ) was autoclaved before use if not specified otherwise.

\subsection{Protein $\mathrm{O}_{3} / \mathrm{NO}_{2}$ exposure setup}

Reactions of BSA with $\mathrm{O}_{3} / \mathrm{NO}_{2}$ mixtures were performed both homogeneously in aqueous solutions and heterogeneously via the exposure of BSA-coated glass tubes to gaseous $\mathrm{O}_{3} / \mathrm{NO}_{2}$ at different levels of relative humidity $(\mathrm{RH})$. Before the exposure experiments, BSA solutions $\left(0.6 \mathrm{~mL}, 0.33 \mathrm{mg} \mathrm{mL}^{-1}\right)$ were loaded into the glass tube and dried by passing a nitrogen $\left(\mathrm{N}_{2}, 99.999 \%\right)$ flow at $\sim 1 \mathrm{~L} \mathrm{~min}^{-1}$ through a specific rotating device, ${ }^{27}$ which is essential to ensure homogeneous coating and experiment reproducibility. The BSA-coated glass tube was then connected to the experimental setup. The experimental setup (Fig. S1, ESI $\dagger$ ) was described previously, ${ }^{20}$ and was extended by incorporating an additional flow of $\mathrm{NO}_{2}$ after the humidifier.

Briefly, ozone was produced from synthetic air passed through a UV lamp (L.O.T.-Oriel GmbH \& Co. KG, Germany) at $\sim 1.9 \mathrm{~L} \mathrm{~min}^{-1}$. The gas flow was then split and one flow was passed through a Nafion ${ }^{\circledR}$ gas humidifier (MH-110-12F-4, PermaPure, USA) operated with autoclaved high purity water, while the other flow remained dry. RH could be varied in a wide range by adjusting the ratio between the dry and humidified air flow. During the experiments, the standard deviation from the set $\mathrm{RH}$ values was $<2 \% \mathrm{RH}$. The gas flow with a set $\mathrm{O}_{3}$ concentration and $\mathrm{RH}$ was then mixed with a $\mathrm{N}_{2}$ flow containing $\sim 5 \mathrm{ppmV} \mathrm{NO}_{2}$ (Air Liquide, Germany). The $\mathrm{NO}_{2}$ concentrations were adjusted by varying the flow rate $(20-80 \mathrm{~mL}$ $\min ^{-1}$ ) of the $\sim 5$ ppmV $\mathrm{NO}_{2}$ flow. The combined gas flow was then directed through the BSA-coated glass tube. The concentrations of $\mathrm{O}_{3}$ and $\mathrm{NO}_{2}$ as well as $\mathrm{RH}$ were measured using commercial monitoring instruments (Ozone analyzer, 
49i, Thermo Scientific, Germany; $\mathrm{NO}_{x}$ analyzer, 42i-TL, Thermo Scientific, Germany; RH sensor FHA 646-E1C with ALMEMO 2590-3 instrument, Ahlborn, Messund Regelungstechnik, Germany). After exposure, the proteins were extracted from the glass tube with $1.5 \mathrm{~mL}$ of $1 \times$ Tris/glycine/SDS (pH 8.3) buffer to avoid precipitation of protein oligomers in the extract solution.

For homogeneous bulk solution reactions, the $\mathrm{O}_{3} / \mathrm{NO}_{2}$ gas mixtures were directly bubbled through $1.5 \mathrm{~mL}$ of $0.13 \mathrm{mg} \mathrm{mL}^{-1} \mathrm{BSA}$ aqueous solutions (pH 7.0 \pm 0.2 ; measured by a pH meter, model WTW multi 350i, WTW, Germany) at a flow

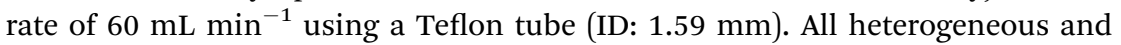
homogeneous exposure experiments were performed in duplicate.

\subsection{SEC-HPLC-DAD analysis}

Product analysis was performed using high-performance liquid chromatography coupled to diode array detection (HPLC-DAD, Agilent Technologies 1200 series). The HPLC-DAD system consisted of a binary pump (G1379B), an autosampler with a thermostat (G1330B), a column thermostat (G1316B), and a photodiode array detector (DAD, G1315C). ChemStation software (Rev. B.03.01, Agilent) was used for system control and data analysis. Molecular weight (MW) separation by size exclusion chromatography (SEC) was carried out using an AdvanceBio SEC column (Agilent, $300 \AA$, $300 \times 4.6 \mathrm{~mm}, 2.7 \mu \mathrm{m}$ ). Isocratic separation at a flow rate of $0.35 \mathrm{~mL} \mathrm{~min}{ }^{-1}$ was carried out using a mobile phase of $150 \mathrm{mM} \mathrm{NaH} \mathrm{mO}_{4}$ buffer (adjusted to $\mathrm{pH} 7$ with $10 \mathrm{M} \mathrm{NaOH}(\mathrm{aq})$ ) after injecting $40 \mu \mathrm{L}$ of sample. The absorbance was monitored by the DAD at wavelengths of 220, 280 and $357 \mathrm{~nm}$. Each chromatographic run was performed in duplicate.

A protein standard mix 15-600 kDa (69385, Sigma Aldrich, Germany) containing bovine thyroglobulin ( $\mathrm{MW}=670 \mathrm{kDa}$ ), $\gamma$-globulin from bovine blood $(\mathrm{MW}=150 \mathrm{kDa})$, chicken egg albumin, grade VI $(\mathrm{MW}=44.3 \mathrm{kDa})$, and ribonuclease A ( $\mathrm{MW}=13.7 \mathrm{kDa}$ ) was used for SEC column calibration (elution time $v s$. $\log$ MW). Details can be found in Fig. S2 in the ESI. $\dagger$ It should be noted that SEC separates molecules according to their hydrodynamic sizes, thus only approximate molecular masses can be obtained by this calibration method.

\subsection{Determination of protein oligomer mass fractions and nitration degrees}

A detailed description of the simultaneous determination of protein oligomer mass fractions and nitration degrees using the SEC-HPLC-DAD analysis described above can be found in Liu et al. ${ }^{28}$ Briefly, we report the formation of BSA oligomers as the temporal evolution in the ratios of the respective oligomers (dimers, trimers, and oligomers with $n \geq 4$ ) to the sum of monomer and all oligomer peak areas at the absorption wavelength of $220 \mathrm{~nm}$. Assuming that the molar extinction coefficients of the individual protein oligomer fractions are multiples of the monomer extinction coefficient, the calculated oligomer ratios correspond to the mass fractions $(\omega)$ of the individual oligomers. Nitration degrees (NDs), defined as the concentration of nitrotyrosine (NTyr) divided by the sum of the concentrations of NTyr and Tyr, were obtained for BSA monomers and dimers, using the respective peak areas of the monomer and dimer signals at wavelengths of $280 \mathrm{~nm}$ and $357 \mathrm{~nm}$. For calculation of the total protein ND, the sum of the peak areas of all protein signals at wavelengths of $280 \mathrm{~nm}$ and $357 \mathrm{~nm}$ was used. Note that corresponding to the definition of the ND, the same number of nitrated Tyr 
residues in a BSA monomer and dimer will lead to a factor of 2 difference in the individual NDs, because a BSA dimer contains twice the number of Tyr residues compared to the monomer. Further information on the calculation of NDs can be found in Liu et $a .^{28}$ The values and errors of the calculated NDs and oligomer mass fractions represent the arithmetic mean values and standard deviations of duplicate experiments. ${ }^{29}$ The commercially available BSA also contains dimers and trimers of the protein as well as pre-nitrated monomers and dimers $(\sim$ NDs $0.9 \%$ ). Therefore, the reported values of oligomer mass fractions and NDs were corrected for these background signals.

\section{Results and discussion}

\subsection{Protein oligomerization}

Fig. 1 and 2 show the effects of varying $\mathrm{NO}_{2}$ and $\mathrm{O}_{3}$ concentrations on protein oligomerization for homogeneous bulk solution and coated-wall flow-tube experiments, respectively. Exposures were carried out at fixed $\mathrm{NO}_{2}$
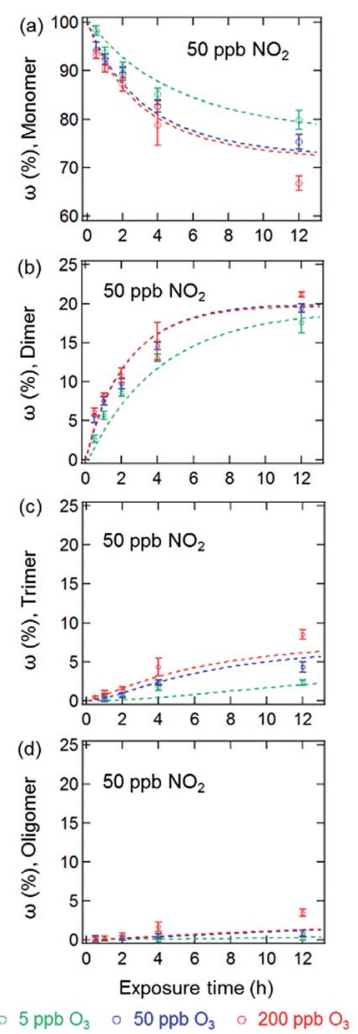
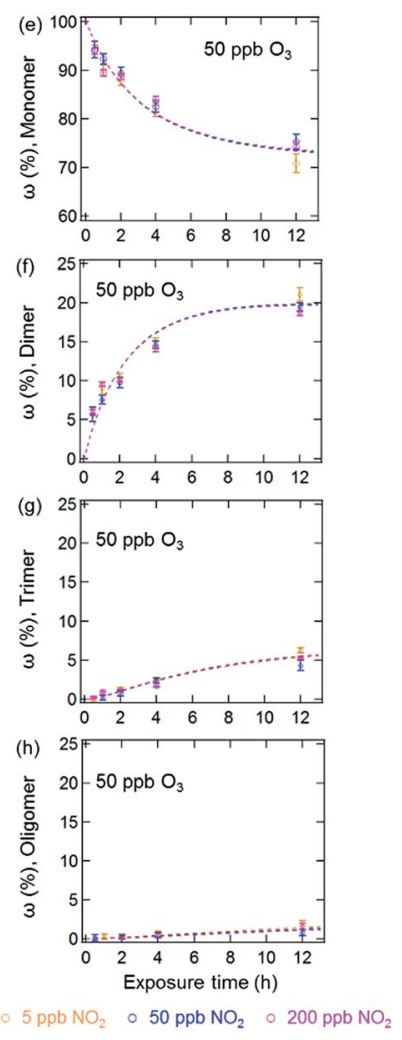

Fig. 1 Temporal evolution of protein oligomer mass fractions $(\omega(\%)$, monomer, dimer, trimer and oligomer $(n \geq 4))$ in the aqueous phase reaction of BSA with $\mathrm{O}_{3} / \mathrm{NO}_{2}$ : ((a) - (d)) at a fixed $\mathrm{NO}_{2}$ concentration of $50 \mathrm{ppb}$ with varied $\mathrm{O}_{3}$ concentrations; ((e)-(h)) at a fixed $\mathrm{O}_{3}$ concentration of $50 \mathrm{ppb}$ with varied $\mathrm{NO}_{2}$ concentrations. The data points and error bars represent the arithmetic mean values and standard deviations of duplicate experiments. The dashed lines are the results of the kinetic model. 

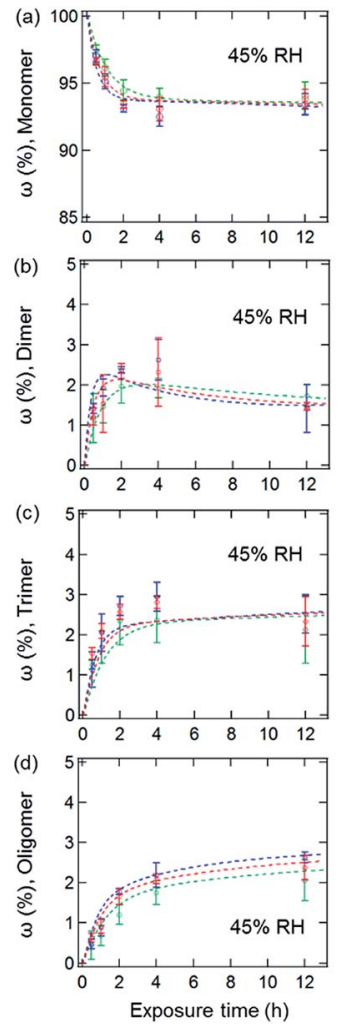

- $50 \mathrm{ppb} \mathrm{O}_{3}, 50 \mathrm{ppb} \mathrm{NO} 2$ ○ $200 \mathrm{ppb} \mathrm{O}_{3}, 50 \mathrm{ppb} \mathrm{NO}$ ○ $200 \mathrm{ppb} \mathrm{O}_{3}, 200 \mathrm{ppb} \mathrm{NO}_{2}$
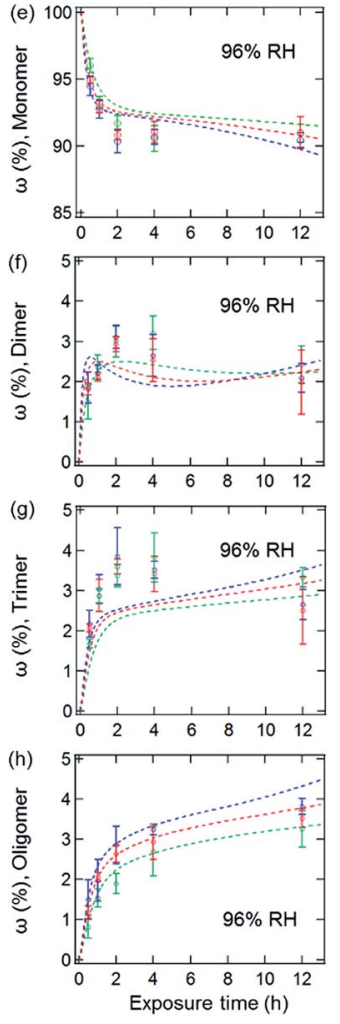

Fig. 2 Temporal evolution of protein oligomer mass fractions ( $\omega(\%)$, monomer, dimer, trimer and oligomer $(n \geq 4)$ ) upon exposure of BSA films (thickness $34 \mathrm{~nm}$ ) to various $\mathrm{O}_{3} /$ $\mathrm{NO}_{2}$ concentrations: ((a)-(d)) at $45 \% \mathrm{RH}$; ((e)-(h)) at $96 \% \mathrm{RH}$. The data points and error bars represent the arithmetic mean values and standard deviations of duplicate experiments. The dashed lines are the results of the kinetic model.

concentrations with varying $\mathrm{O}_{3}$ concentrations and vice versa. The exposure time was varied from 0.5 up to $12 \mathrm{~h}$. While in bulk solution experiments dimers were generally observed as the major reaction products of BSA with $\mathrm{O}_{3}$ and $\mathrm{NO}_{2}$, trimers or higher oligomers can be dominant products in the coated-wall flowtube experiments at longer exposure times, depending on the experimental conditions.

The results of the bulk solution experiments on protein oligomerization are illustrated in Fig. 1. Generally, the mass fractions of dimers, trimers, and higher oligomers increase with increasing reaction times, reaching up to $21 \pm 1 \%$ for dimers, $9 \pm 1 \%$ for trimers, and $4 \pm 1 \%$ for oligomers with $n \geq 4$ after $12 \mathrm{~h}$ of exposure. The minimum mass fraction of monomers correspondingly was found to be $66 \%$. While varying the $\mathrm{O}_{3}$ concentrations (Fig. 1a-d, fixed $50 \mathrm{ppb}$ of $\mathrm{NO}_{2}$ ) from 5 to $200 \mathrm{ppb}$ significantly affected the temporal evolutions observed for the mass fractions of the different oligomers, changing the $\mathrm{NO}_{2}$ concentration (Fig. 1e-h, fixed $50 \mathrm{ppb}$ of $\mathrm{O}_{3}$ ) in the same range did not result in significant changes in oligomer mass fractions. The solubility of $\mathrm{O}_{3}$ and $\mathrm{NO}_{2}$ in water is 
$\sim 10^{-5} \mathrm{~mol} \mathrm{~mL}^{-1}$ (derived from their Henry's law constants: $K_{\mathrm{sol}, \mathrm{cc}, \mathrm{O}_{3}} \approx K_{\mathrm{sol}, \mathrm{cc}, \mathrm{NO}_{2}}$ $\left.\approx 10^{-2} \mathrm{M} \mathrm{atm}^{-1}\right)^{30}$ under our experimental conditions. Increasing $\mathrm{O}_{3}$ and $\mathrm{NO}_{2}$ gas concentrations between 5 to $200 \mathrm{ppb}$ should result in concentrations of $\mathrm{O}_{3}$ and $\mathrm{NO}_{2}$ between $7 \times 10^{-11}$ to $3 \times 10^{-9} \mathrm{M}$ in the aqueous phase. Thus, the insignificant change of oligomer mass fractions with varied $\mathrm{NO}_{2}$ concentration should not be caused by a saturation of dissolved $\mathrm{NO}_{2}$ in the concentration range investigated (5 to $200 \mathrm{ppb}$ ).

Mechanistically, the reactions between $\mathrm{O}_{3} / \mathrm{NO}_{2}$ and protein Tyr residues involve the formation of ROIs (tyrosyl radicals) resulting from the reaction of Tyr with $\mathrm{O}_{3}$. These ROIs can then either react with $\mathrm{NO}_{2}$ to form NTyr residues or crosslink due to intermolecular DTyr formation. ${ }^{6,20}$ Ozonolysis of Tyr may also result in other oxidized products such as 3,4-dihydroxyphenylalanine (DOPA). ${ }^{31}$ However, the reaction mechanism for the formation of these oxidized products is not the focus of this study and we only consider these modified Tyr derivatives in the proposed mechanism (Table S1 $\dagger$ ) as a portion of the oxidized amino acid residues. Regardless, an inhibition of intermolecular DTyr cross-linking would be expected with increasing $\mathrm{NO}_{2}$ concentrations. However, no such behavior was observed. Furthermore, similar protein oligomer mass fractions were observed previously in the absence of $\mathrm{NO}_{2}$ for BSA exposed to $\mathrm{O}_{3}$ in bulk solution experiments with comparable levels of $\mathrm{O}_{3}(50$ and $200 \mathrm{ppb}) .^{20}$ This observation may be due to the high number of accessible Tyr residues on the dissolved BSA molecules in solution, because after $12 \mathrm{~h}$ of exposure, $66 \%$ of BSA (Fig. 1a) is still present in monomeric form.

The results of the coated-wall flow-tube experiments on protein oligomerization are illustrated in Fig. 2. In these experiments, thin protein films were exposed to $\mathrm{O}_{3} / \mathrm{NO}_{2}$ mixtures. A film thickness of $\sim 34 \mathrm{~nm}$, or roughly five layers of BSA, can be calculated assuming an even distribution of the BSA molecules on the inner surface of the glass tube. ${ }^{20}$ The experiments were performed at $45 \%$ and $96 \% \mathrm{RH}$ with $\mathrm{O}_{3} / \mathrm{NO}_{2}$ concentrations of 50/50, 200/50, and 50/200 ppb, respectively. Generally, the reactive sites accessible for oligomerization reactions of the proteins are limited here compared to aqueous solutions, leading to smaller mass fractions of protein oligomers. Furthermore, we observed a $30-40 \%$ reduction of the overall oligomer mass fraction (dimer, trimer, and oligomer $\geq 4$ ) compared to similar flow-tube experiments in the absence of $\mathrm{NO}_{2}$ for comparable $\mathrm{RH}$ and $\mathrm{O}_{3}$ concentrations..$^{20}$ Apparently, the lower diffusivity of the proteins in this solid ( $45 \% \mathrm{RH})$ or semi-solid (96\% RH) state induces a competition between DTyr and NTyr formation, also indicated by the observation of slower reaction rates for oligomerization in the bulk of the thin protein film compared to its surface. ${ }^{20,23}$

In contrast to the bulk solution experiments, which show a steady increase of the oligomer mass fractions with exposure time, dimer and trimer mass fractions in the flow tube experiments peaked at exposure times of $2-4 \mathrm{~h}$, depending on $\mathrm{RH}$ and trace gas concentrations, while only higher oligomers steadily increased over the course of the reaction time (see Fig. 2). This result indicates that as the exposure proceeds, the formation of dimers and trimers becomes slower than their consumption converting them into higher oligomers. The characteristic residence times (lifetimes) of biological particles in the atmosphere can range from hours to weeks, depending on their sizes, aerodynamic, and hygroscopic properties. $^{32}$ Our observation indicates that the initial exposure $(<2-4 \mathrm{~h})$ of proteins to $\mathrm{O}_{3}$ and $\mathrm{NO}_{2}$ mainly leads to the formation of protein dimers and 
trimers, and as the exposure proceeds, protein oligomers could be the dominant protein species, e.g., on the surface of bioaerosol particles.

\subsection{Protein nitration}

Fig. 3 and 4 show the effects of varying $\mathrm{NO}_{2}$ and $\mathrm{O}_{3}$ concentrations on the nitration of protein monomers and dimers in homogeneous bulk solution and coated-wall flow-tube experiments, respectively. Exposures were carried out at fixed $\mathrm{NO}_{2}$ concentrations with varying $\mathrm{O}_{3}$ concentrations and vice versa. The exposure time was varied from 0.5 up to $12 \mathrm{~h}$. While in previous studies total protein nitration degrees (NDs) were investigated upon exposure to $\mathrm{O}_{3}$ and $\mathrm{NO}_{2},{ }^{12,33}$ we explicitly explored and characterized the reaction kinetics of protein nitration, resolving the individual NDs of the protein monomer and its various oligomers over the course of reaction time.

The results of the bulk solution experiments on protein nitration are illustrated in Fig. 3. The maximum ND of protein monomers and dimers were found to be $7 \%$ and $5 \%$ after $12 \mathrm{~h}$ exposure to $200 \mathrm{ppb} \mathrm{O}_{3}$ and $50 \mathrm{ppb} \mathrm{NO}_{2}$, respectively. These results correspond to 1.4 NTyr residues per monomer molecule and 2 NTyr residues per dimer molecule (NTyr/monomer and NTyr/dimer are shown as secondary $y$-axes in Fig. 3 and 4). We found a positive relationship between the NDs and $\mathrm{O}_{3}$ concentration (Fig. 3a and b), particularly that the increase of $\mathrm{O}_{3}$ concentration by one order of magnitude from 5 to $50 \mathrm{ppb}$ resulted in an increase of NDs from $4.2 \pm 0.2 \%$ to $6.9 \pm 0.2 \%$, and $2.0 \pm 0.3 \%$ to $4.5 \pm 0.3 \%$ after $12 \mathrm{~h}$ exposure for the monomer and dimer, respectively. Also, for protein nitration, no significant difference was found when concentrations of $\mathrm{NO}_{2}$ were varied from 5 to $200 \mathrm{ppb}$ at a fixed $\mathrm{O}_{3}$ concentration of $50 \mathrm{ppb}$, as shown in Fig. $3 \mathrm{c}$ and d. These results are in accordance with the observations made by Shiraiwa et al. ${ }^{23}$ on the
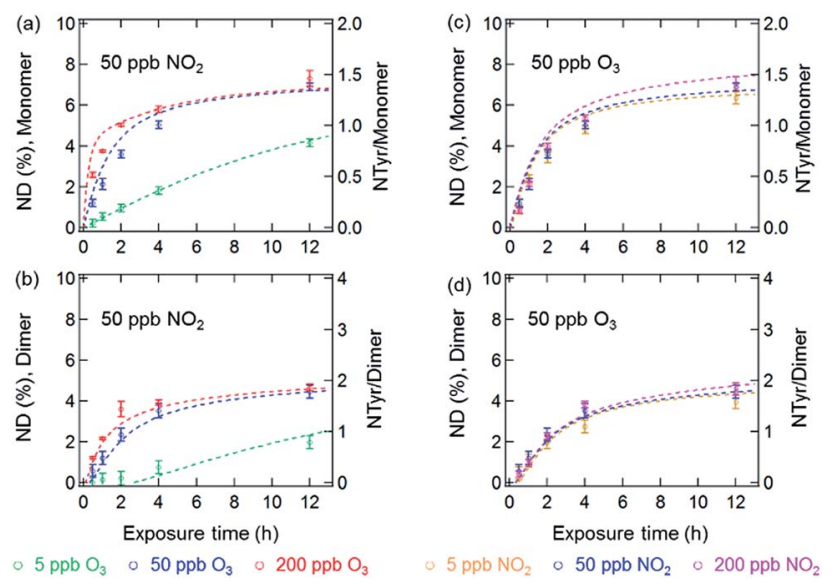

Fig. 3 NDs of protein monomer and dimer (primary $y$-axis), and NTyr number per monomer and dimer (secondary $y$-axis) plotted against reaction time in the aqueous phase reaction of $\mathrm{BSA}$ with $\mathrm{O}_{3} / \mathrm{NO}_{2}$ : (a) and (b) at a fixed $\mathrm{NO}_{2}$ concentration of $50 \mathrm{ppb}$ with varied $\mathrm{O}_{3}$ concentrations, and (c) and (d) at a fixed $\mathrm{O}_{3}$ concentration of $50 \mathrm{ppb}$ with varied $\mathrm{NO}_{2}$ concentrations. The data points and error bars represent the arithmetic mean values and standard deviations of duplicate experiments. The dashed lines are the results of the kinetic model. 

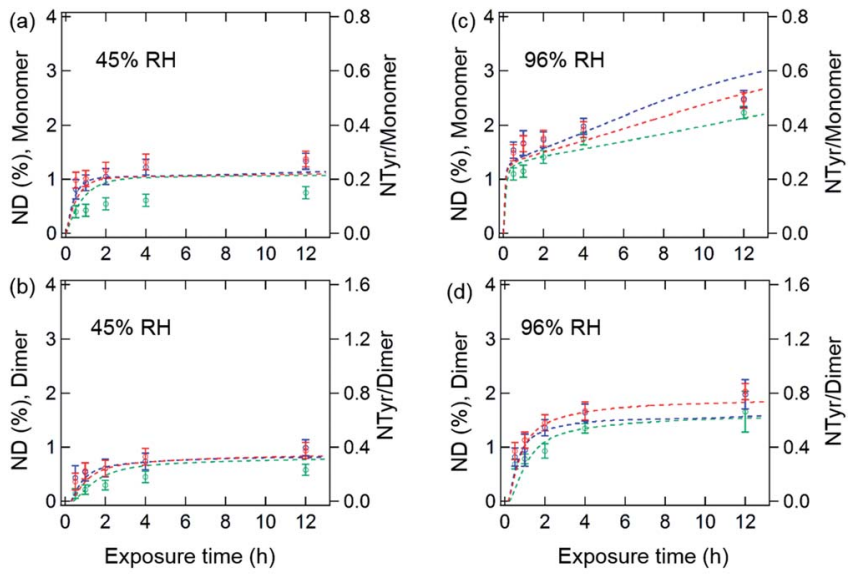

- $50 \mathrm{ppb} \mathrm{O}, 50 \mathrm{ppb} \mathrm{NO} \mathrm{NO}_{2} \circ 200 \mathrm{ppb} \mathrm{O}_{3}, 50 \mathrm{ppb} \mathrm{NO}_{2} \circ 200 \mathrm{ppb} \mathrm{O}_{3}, 200 \mathrm{ppb} \mathrm{NO}$

Fig. 4 NDs of protein monomer and dimer (primary $y$-axis), and NTyr number per monomer and dimer (secondary $y$-axis) plotted against exposure time upon the exposure of BSA films (thickness $34 \mathrm{~nm}$ ) to various $\mathrm{O}_{3} / \mathrm{NO}_{2}$ concentrations: (a) and (b) at $45 \% \mathrm{RH}$, and (c) and (d) at $96 \% \mathrm{RH}$. The data points and error bars represent the arithmetic mean values and standard deviations of duplicate experiments. The dashed lines are the results of the kinetic model.

study of the reactive uptake of $\mathrm{NO}_{2}$ by aerosolized proteins. They found that the uptake coefficient of $\mathrm{NO}_{2}\left(\gamma_{\mathrm{NO}_{2}}\right)$ increased with increasing $\mathrm{O}_{3}$ concentrations while $\gamma_{\mathrm{NO}_{2}}$ decreased gradually with increasing $\mathrm{NO}_{2}$ concentration. Thus, our results confirm that the protein reaction with $\mathrm{O}_{3}$ and formation of ROI is the ratelimiting step for protein nitration. ${ }^{21,23}$ Shiraiwa et al. ${ }^{23}$ have excluded $\mathrm{NO}_{3}$ or $\mathrm{N}_{2} \mathrm{O}_{5}$ (formed through $\mathrm{NO}_{2}$ oxidation by $\mathrm{O}_{3}$ ) as major contributors to protein nitration. Ghiani et al. ${ }^{34}$ reported that nitration of proteins can also occur by nitrate ions in bulk solutions without UV irradiation under acidic conditions ( $\mathrm{pH}<3$ for BSA). The reaction of $\mathrm{NO}_{2}$ with water can form nitric acid and thereby nitrate ions might appear in the BSA solution. However, we found that the $\mathrm{pH}$ of the BSA solutions stayed relatively constant ( $\mathrm{pH} 6.6 \pm 0.2 ; \mathrm{pH}$ meter model WTW multi 350i) for a reaction time of $12 \mathrm{~h}$ at $200 \mathrm{ppb} \mathrm{NO}_{2}$ and $50 \mathrm{ppb} \mathrm{O}_{3}$, indicating that nitration induced by nitrate ions is likely a minor or negligible pathway in this study. This hypothesis is consistent with the results in Fig. 3c and d that show only a slight increase in ND (monomer, $6.3 \pm 0.3 \%$ to $6.9 \pm 0.2 \%$, and dimer, $4.0 \pm 0.3 \%$ to 4.5 $\pm 0.3 \%$, for $12 \mathrm{~h}$ reaction) for a one order of magnitude increase in the $\mathrm{NO}_{2}$ concentration from 5 to $50 \mathrm{ppb}$.

The results of the temporal increase of NDs of monomer and dimer for reactions of the thin protein films with $\mathrm{O}_{3}$ and $\mathrm{NO}_{2}$ concentrations of 50 and $200 \mathrm{ppb}$ at $45 \%$ and $96 \% \mathrm{RH}$ are illustrated in Fig. 4 . Here, the NDs for monomer and dimer at $45 \% \mathrm{RH}$ were found to be around $1 \%$ and $0.8 \%$ for $12 \mathrm{~h}$ exposure, corresponding to $0.2 \mathrm{NTyr} /$ monomer molecule and $0.3 \mathrm{NTyr} /$ dimer molecule. Note that the protein coating consisted of $\sim 5$ layers. Therefore, the results likely indicate that on average one Tyr per BSA monomer molecule located on the surface of the protein film was efficiently nitrated, while the bulk nitration occurred at much slower rates. This highly reactive site could be the Tyr residue at 
position 161 (Y161), as suggested by Zhang et al. ${ }^{35}$ The maximum NDs for monomer and dimer reached up to $2.5 \pm 0.1 \%$ and $2.0 \pm 0.1 \%$ at $96 \% \mathrm{RH}$, respectively. However, both of the maximum NDs at $45 \%$ and $96 \% \mathrm{RH}$ were much lower than those obtained for $\mathrm{O}_{3} / \mathrm{NO}_{2}$ exposure in aqueous solutions $\left(200 \mathrm{ppb} \mathrm{O}_{3}\right.$ and $50 \mathrm{ppb} \mathrm{NO}_{2}$ ). This discrepancy can be explained by a decrease in viscosity and an increase in diffusivity on going from an amorphous solid (45\% $\mathrm{RH}$ ) or semisolid $(96 \% \mathrm{RH})$ protein on a coated wall to an aqueous protein solution and was able to be reproduced using a model (see below) ${ }^{36,37}$ Furthermore, the NDs of BSA in this study are comparable to those found by Yang et al..$^{33}$ using the same protein, whereas the nitration efficiency of BSA in general is found to be much lower than the one observed for the major birch pollen allergen Bet $\mathrm{v} 1$ in similar exposure experiments, ${ }^{\mathbf{1 2}}$ indicating a strong influence of molecular structure and potentially the amino acid sequence of the reacting protein. From previous mass spectrometric analysis of the site selectivity of protein nitration by $\mathrm{O}_{3} / \mathrm{NO}_{2}$, it is known that only 3 out of 21 Tyr residues in BSA can be detected in the nitrated form, while in Bet v 1, 4 out of 7 Tyr residues can be nitrated. ${ }^{\mathbf{1 2 , 3 5}}$ Thus, besides the types of nitrating agents (e.g. $\mathrm{ONOO}^{-}$or $\mathrm{O}_{3} / \mathrm{NO}_{2}$ ) and reaction conditions (in aqueous solution or heterogeneous exposure), the nitration efficiency also depends on the fraction of reactive Tyr residues in the investigated protein.

\subsection{Kinetics and mechanism of protein nitration and oligomerization by $\mathrm{O}_{3} /$ $\mathrm{NO}_{2}$}

The model results for the reactions of proteins with $\mathrm{O}_{3} / \mathrm{NO}_{2}$ under the various exposure conditions are shown as the dashed lines in Fig. 1-4. A chemical mechanism involving 19 reactions (see Table S1† for details) was applied in two kinetic models, i.e., a box model for bulk solution experiments and a kinetic multilayer model for aerosol surface and bulk chemistry (KM-SUB $)^{26}$ for flow tube

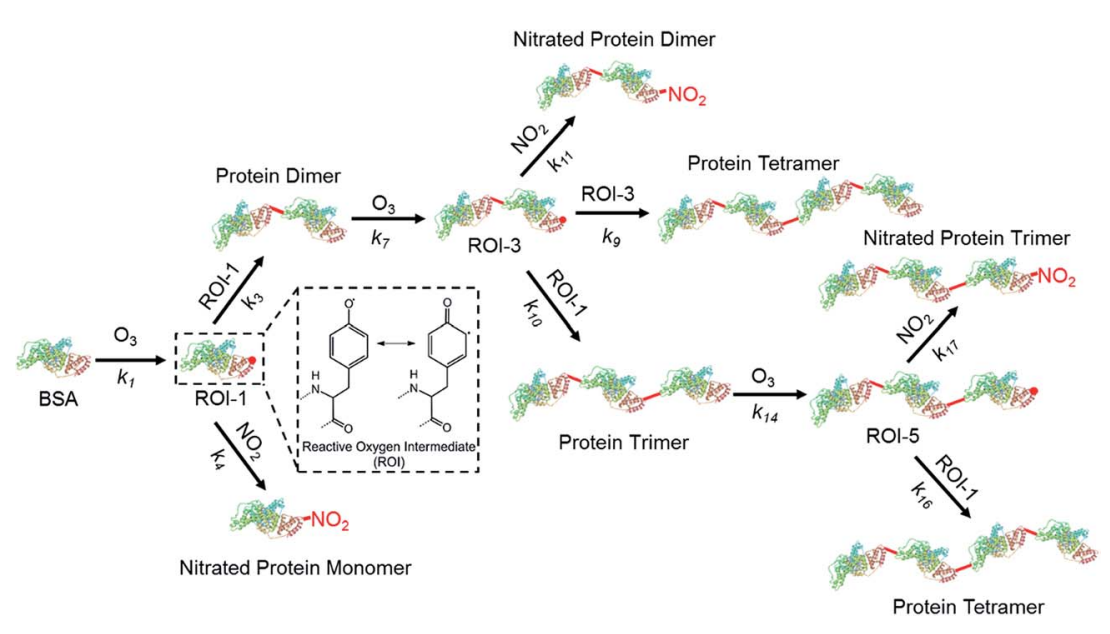

Fig. 5 Schematic overview of the most relevant reactions for protein nitration and oligomerization upon exposure to ozone and nitrogen dioxide. The reactions correspond to protein surface Tyr nitration and oligomerization in the mechanism presented in Table S1. $\dagger$ The molecular structure of the protein (BSA, PDB accession number 3V03) was created using RCSB PDB protein workshop (4.2.0) software. 
experiments to fit the experimental data. The most relevant reactions for this mechanism are illustrated in Fig. 5. The first step in the mechanism is the reaction of a Tyr residue with $\mathrm{O}_{3}$ forming tyrosyl radicals as long-lived reactive oxygen intermediates (ROIs). In the second step of the process, the ROIs can react with each other to form dimers, or with $\mathrm{NO}_{2}$ to form nitrated monomers. Note that for simplification, each molecule only contains one reactive tyrosine residue, while nitrated and oxidized monomers, dimers and trimers are unable to take part in further reactions in the kinetic model. A dimer can react further with $\mathrm{O}_{3}$ to form a dimeric ROI, which may react with $\mathrm{NO}_{2}$ to form a nitrated protein dimer, with monomeric ROI to form a protein trimer or with another dimeric ROI to form a protein tetramer.

The following assumptions were made to enable modelling of the reaction system for bulk solution and coated-wall flow-tube experiments using the sets of physicochemical parameters shown in Table S1 (ESI $\dagger$ ): BSA molecules have reactive amino acid residues on their surface (AA1) and in their bulk (AA2), both of them reactive towards $\mathrm{O}_{3}$. While ROIs formed in the protein bulk can only react with $\mathrm{NO}_{2}$ to form NTyr, they are unable to form intermolecular DTyr due to steric hindrance. ${ }^{38}$ These assumptions were also applied to dimers and trimers. Besides Tyr, $\mathrm{O}_{3}$ can also oxidize other amino acid residues, i.e., cysteine (Cys), tryptophan (Trp), methionine (Met) and histidine (His). ${ }^{31}$ Among them, only Cys is able to cross-link proteins directly upon $\mathrm{O}_{3}$ exposure, yielding intermolecular disulfide bridges, as one free Cys is available in BSA. ${ }^{39}$ This reversible cross-linking mechanism has been shown to be only a minor contributor to protein oligomerization upon $\mathrm{O}_{3} / \mathrm{NO}_{2}$ exposure previously. ${ }^{20}$ The kinetic parameters were obtained using a global optimization method combining a uniformly-sampled Monte Carlo search with a genetic algorithm (MCGA method). ${ }^{\mathbf{4 0 , 4 1}}$ The genetic algorithm was terminated when the correlation between experimental data and model output reached an optimum. Concentrations of $\mathrm{O}_{3}$ and $\mathrm{NO}_{2}$ in the aqueous phase can be estimated using the published Henry's law constant of $K_{\text {sol,cc, } \mathrm{O}_{3}} \approx$ $K_{\text {sol,cc, } \mathrm{NO}_{2}} \approx 10^{-2} \mathrm{M} \mathrm{atm}{ }^{-1}$, which were used as fixed values in the model. ${ }^{30}$

The temporal evolution of NDs and oligomer mass fractions in aqueous solution is well reproduced by the model (Fig. 1 and 3). For the heterogeneous reactions studied in the coated-wall flow-tube experiments at $45 \% \mathrm{RH}$ and $96 \%$ $\mathrm{RH}$, some substantial deviations between modelled and measured data can be observed, and the coefficient of determination ( $R^{2}$ value) is approximately a factor of two lower than for the aqueous data. For example, the oligomer mass fractions $\omega$ at $45 \%$ RH in Fig. $2 a-d$ are qualitatively captured fairly well, while the model fails to reproduce their evolution at higher $\mathrm{RH}$, especially for the dimer and trimer (Fig. 2f and g). The observed reduction of dimers in flow tube experiments could be reproduced by the model including the reactions on the surface, where the rates are four orders of magnitude higher than that of bulk reactions. Despite simple model assumptions when describing the complex reaction system that was studied, the model reproduces the experimental data reasonably well with an overall $R^{2}$ value of 0.88 for Fig. $1-4$. Most of the optimized parameters obtained for the flow tube experiments were close to or the same as those for aqueous solutions (for details see Table S1, ESI $\dagger$ ). However, note that some of the rate coefficients would be expected to change as the liquid water content and viscosity varies. Water could actively take part in some of the reactions and its presence at different concentrations could lead to changes in experimental conditions, such 
as $\mathrm{pH}$, which would influence the rate of the reactions. As the viscosity increases it is also expected that some rate coefficients would decrease as they become diffusion-limited as per the Smoluchowski diffusion equation. ${ }^{42,43}$

The second-order rate coefficients obtained as model outputs and shown in Table $\mathrm{S} 1 \dagger$ are mostly consistent with previous studies. ${ }^{\mathbf{2 0}, 23}$ However, as the complex reaction mixture has been reflected in only 19 chemical reactions, the absolute numbers of the rate coefficients obtained for the individual reactions likely do not reflect reality, because further secondary chemistry of various kinds is not included explicitly. It should also be noted that different types of tyrosine residues have not been explicitly included within the model, although these can nitrate at different rates and have different surface accessibilities. ${ }^{35,44}$ Nevertheless, qualitatively, the model results suggest that protein nitration occurs at faster rates than protein oligomerization. The observed and modelled preference of nitration over oligomerization can be rationalized by comparing the mass fraction of nitrated monomer (calculated by multiplying the mass fraction of monomer with NTyr/monomer) with the total oligomer mass fraction. Nitrated monomers were observed to have two times or higher mass fractions compared to all other oligomer mass fractions combined under all experimental conditions. This result indicates that Tyr nitration outcompetes the dimerization/oligomerization process. ${ }^{22,45}$

\section{Implications and conclusions}

In this study we investigated the kinetics and mechanism of the nitration and oligomerization of proteins induced by $\mathrm{O}_{3}$ and $\mathrm{NO}_{2}$ under different atmospherically relevant conditions. We showed the concentration and time dependence of the formation of dimers, trimers and higher protein oligomers as well as their individual nitration degrees. The temporal evolution of the concentrations of these multiple reaction products was well reproduced by a kinetic model with 19 chemical reactions. Protein nitration was found to be kinetically favored over protein oligomerization under the experimental conditions studied in this work. On the basis of the observation that nitrated oligomers formed upon exposure to $\mathrm{O}_{3} / \mathrm{NO}_{2}$, we suggest further investigation on the allergenic and immunogenic effects by nitrated protein oligomers. The nitrated oligomers were also found in the physiologically-relevant peroxynitrite-induced protein nitration and oligomerization, ${ }^{46}$ for which the mechanism is similar to the one we reported here. ${ }^{25,47}$

The implications of protein chemistry with $\mathrm{O}_{3}$ and $\mathrm{NO}_{2}$ under atmospherically relevant conditions are illustrated in Fig. 6. The overall nitration and oligomerization rates were both almost one order of magnitude higher in the aqueous phase than for $45 \% \mathrm{RH}$, indicating an increased relevance of the processes under cloud-processing conditions. Also, the yields of protein nitration and oligomerization can be strongly influenced by changes in relative humidity leading to changes of phase states. The protein dimers can yield up to $20 \%$ (by mass) for $12 \mathrm{~h}$ exposure in the liquid phase and the NDs of monomers and dimers can be up to $7 \%$ and $5 \%$, respectively. This result indicates that on average, 1.4 Tyr residues in each monomeric protein molecule and 2 Tyr residues in each dimeric molecule are present in their nitrated forms. For proteins in solid or semi-solid phase states, our measurement and model results suggest that higher protein oligomers are likely to be found at lower RH, e.g., on the surface of bioaerosols, whereas the 


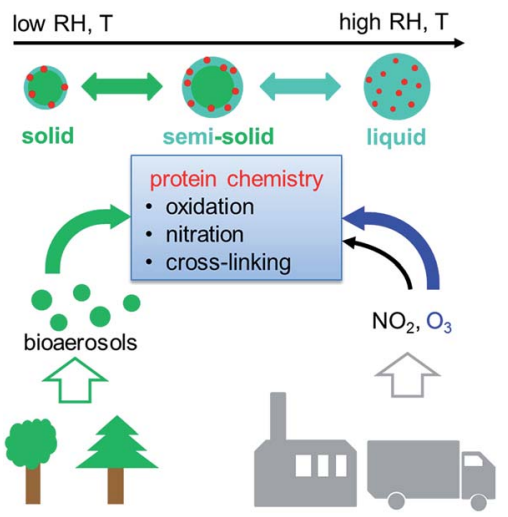

Fig. 6 Atmospheric protein chemistry by ozone $\left(\mathrm{O}_{3}\right)$ and nitrogen dioxide $\left(\mathrm{NO}_{2}\right)$. Reaction rates are limited by the phase state of proteins and hence the diffusivity of oxidants and protein molecules, which changes with relative humidity $(\mathrm{RH})$ and temperature $(T)$. Air pollutants such as $\mathrm{NO}_{2}$ and $\mathrm{O}_{3}$ can enhance allergen release from bioaerosols (e.g., pollen) with $\mathrm{O}_{3}$ being more important in triggering the nitration, cross-linking and oxidation of allergenic proteins in bioaerosols and other protein-containing particles (e.g., Bet v 1 on urban road dust ${ }^{15}$ ).

NDs of monomers and dimers remain at $\sim 1-2 \%$. Using ab initio calculations, Sandhiya et al. $^{22}$ also showed that increased temperature can speed up the formation of tyrosyl radicals by ozonolysis. Thus, it is expected that nitrated and dimeric protein species could be important products of exposure to $\mathrm{O}_{3}$ and $\mathrm{NO}_{2}$ under tropical or summer smog conditions. These differences in reaction kinetics should be taken into account in studies on the physiological effects of proteins exposed to anthropogenic air pollutants, as the allergenic proteins in various oligomerization and nitration states might have a different immunogenic potential.

Both increasing levels of $\mathrm{O}_{3}$ and $\mathrm{NO}_{2}$ are able to damage pollen grains and facilitate the release of allergens in polluted environments. ${ }^{3,89}$ However, our results show that the tyrosine nitration and cross-linking of proteins are sensitive towards an increase in $\mathrm{O}_{3}$ concentration and rather insensitive towards changes in ambient $\mathrm{NO}_{2}$ concentrations. Therefore, effective control of the enhanced allergenicity induced by air pollutant-modified aeroallergens should point towards the decrease of ambient ozone concentrations.

\section{Acknowledgements}

F. L. and S. L. acknowledge financial support from the China Scholarship Council (CSC). C. J. K. and T. B. acknowledge support by the Max Planck Graduate Center with the Johannes Gutenberg University Mainz (MPGC). C. J. K. acknowledges financial support by the German Research Foundation (DFG; grant no. KA 4008/1-2).

\section{Notes and references}

1 M. I. Asher, S. Montefort, B. Björkstén, C. K. Lai, D. P. Strachan, S. K. Weiland, H. Williams and I. P. T. S. Group, Lancet, 2006, 368, 733-743. 
2 R. Pawankar, C. E. Baena-Cagnani, J. Bousquet, G. W. Canonica, A. A. Cruz, M. A. Kaliner and B. Q. Lanier, World Allergy Organ. J., 2008, 1, S4-S17.

3 U. Frank and D. Ernst, Front. Plant Sci., 2016, 7, 91.

4 K.-H. Kim, S. A. Jahan and E. Kabir, Environ. Int., 2013, 59, 41-52.

5 U. Pöschl and M. Shiraiwa, Chem. Rev., 2015, 115, 4440-4475.

6 K. Reinmuth-Selzle, C. J. Kampf, K. Lucas, N. Lang-Yona, J. Fröhlich-Nowoisky, M. Shiraiwa, P. S. J. Lakey, S. Lai, F. Liu, A. T. Kunert, K. Ziegler, F. Shen, R. Sgarbanti, B. Weber, M. G. Weller, I. Bellinghausen, J. Saloga, A. Duschl, D. Schuppan and U. Pöschl, Environ. Sci. Technol., 2017, 51, 4119-4141.

7 D. Diaz-Sanchez, M. P. Garcia, M. Wang, M. Jyrala and A. Saxon, J. Allergy Clin. Immunol., 1999, 104, 1183-1188.

8 I. Beck, S. Jochner, S. Gilles, M. McIntyre, J. T. Buters, C. Schmidt-Weber, H. Behrendt, J. Ring, A. Menzel and C. Traidl-Hoffmann, PLoS One, 2013, 8, e80147.

9 Y. Ouyang, Z. Xu, E. Fan, Y. Li and L. Zhang, Int. Forum. Allergy Rhinol., 2016, 6, 95-100.

10 C. Ackaert, S. Kofler, J. Horejs-Hoeck, N. Zulehner, C. Asam, S. von Grafenstein, J. E. Fuchs, P. Briza, K. R. Liedl and B. Bohle, PLoS one, 2014, 9, e104520.

11 N. Lang-Yona, T. Shuster-Meiseles, Y. Mazar, O. Yarden and Y. Rudich, Sci. Total Environ., 2016, 541, 365-371.

12 K. Reinmuth-Selzle, C. Ackaert, C. J. Kampf, M. Samonig, M. Shiraiwa, S. Kofler, H. Yang, G. Gadermaier, H. Brandstetter and C. G. Huber, J. Proteome Res., 2014, 13, 1570-1577.

13 A. D. Estillore, J. V. Trueblood and V. H. Grassian, Chem. Sci., 2016, 7, 66046616.

14 J. Fröhlich-Nowoisky, C. J. Kampf, B. Weber, J. A. Huffman, C. Pöhlker, M. O. Andreae, N. Lang-Yona, S. M. Burrows, S. S. Gunthe, W. Elbert, H. Su, P. Hoor, E. Thines, T. Hoffmann, V. R. Després and U. Pöschl, Atmos. Res., 2016, 182, 346-376.

15 T. Franze, M. G. Weller, R. Niessner and U. Pöschl, Environ. Sci. Technol., 2005, 39, 1673-1678.

16 J. T. Buters, A. Kasche, I. Weichenmeier, W. Schober, S. Klaus, C. TraidlHoffmann, A. Menzel, J. Huss-Marp, U. Krämer and H. Behrendt, Int. Arch. Allergy Immunol., 2007, 145, 122-130.

17 F. Liu, S. Lai, K. Reinmuth-Selzle, J. F. Scheel, J. Fröhlich-Nowoisky, V. R. Després, T. Hoffmann, U. Pöschl and C. J. Kampf, Anal. Bioanal. Chem., 2016, 408, 6337-6348.

18 P. Taylor, R. Flagan, A. Miguel, R. Valenta and M. Glovsky, Clin. Exp. Allergy, 2004, 34, 1591-1596.

19 G. F. Schäppi, P. E. Taylor, I. A. Staff, C. Suphioglu and R. B. Knox, Sex. Plant Reprod., 1997, 10, 315-323.

20 C. J. Kampf, F. Liu, K. Reinmuth-Selzle, T. Berkemeier, H. Meusel, M. Shiraiwa and U. Pöschl, Environ. Sci. Technol., 2015, 49, 10859-10866.

21 M. Shiraiwa, Y. Sosedova, A. Rouvière, H. Yang, Y. Zhang, J. P. Abbatt, M. Ammann and U. Pöschl, Nat. Chem., 2011, 3, 291-295.

22 L. Sandhiya, P. Kolandaivel and K. Senthilkumar, J. Phys. Chem. B, 2014, 118, 3479-3490. 
23 M. Shiraiwa, K. Selzle, H. Yang, Y. Sosedova, M. Ammann and U. Pöschl, Environ. Sci. Technol., 2012, 46, 6672-6680.

24 M. Shiraiwa, K. Selzle and U. Pöschl, Free Radical Res., 2012, 46, 927-939.

25 S. Pfeiffer, K. Schmidt and B. Mayer, J. Biol. Chem., 2000, 275, 6346-6352.

26 M. Shiraiwa, C. Pfrang and U. Pöschl, Atmos. Chem. Phys., 2010, 10, 3673-3691.

27 G. Li, H. Su, X. Li, U. Kuhn, H. Meusel, T. Hoffmann, M. Ammann, U. Pöschl, M. Shao and Y. Cheng, Atmos. Chem. Phys., 2016, 16, 10299-10311.

28 F. Liu, K. Reinmuth-Selzle, S. Lai, M. G. Weller, U. Pöschl and C. J. Kampf, J. Chromatogr. A, 2017, 1495, 76-82.

29 S. L. Ellison, M. Rosslein and A. Williams, in Quantifying uncertainty in analytical measurement, Eurachem, 2000.

30 R. Sander, Atmos. Chem. Phys., 2015, 15, 4399-4981.

31 V. K. Sharma and N. J. Graham, Ozone: Sci. Eng., 2010, 32, 81-90.

32 V. R. Després, J. A. Huffman, S. M. Burrows, C. Hoose, A. S. Safatov, G. Buryak, J. Fröhlich-Nowoisky, W. Elbert, M. O. Andreae, U. Pöschl and R. Jaenicke, Tellus, Ser. B, 2012, 64, 1-58.

33 H. Yang, Y. Zhang and U. Pöschl, Anal. Bioanal. Chem., 2010, 397, 879-886.

34 A. Ghiani, M. Bruschi, S. Citterio, E. Bolzacchini, L. Ferrero, G. Sangiorgi, R. Asero and M. G. Perrone, Sci. Total Environ., 2016, 573, 1589-1597.

35 Y. Zhang, H. Yang and U. Pöschl, Anal. Bioanal. Chem., 2011, 399, 459-471.

36 M. Shiraiwa, M. Ammann, T. Koop and U. Pöschl, Proc. Natl. Acad. Sci. U. S. A., 2011, 108, 11003-11008.

37 E. Mikhailov, S. Vlasenko, S. Martin, T. Koop and U. Pöschl, Atmos. Chem. Phys., 2009, 9, 9491-9522.

38 W. H. Heijnis, H. L. Dekker, L. J. de Koning, P. A. Wierenga, A. H. Westphal, C. G. de Koster, H. Gruppen and W. J. van Berkel, J. Agric. Food Chem., 2010, 59, 444-449.

39 T. Ueki, Y. Hiragi, M. Kataoka, Y. Inoko, Y. Amemiya, Y. Izumi, H. Tagawa and Y. Muroga, Biophys. Chem., 1985, 23, 115-124.

40 T. Berkemeier, S. S. Steimer, U. K. Krieger, T. Peter, U. Pöschl, M. Ammann and M. Shiraiwa, Phys. Chem. Chem. Phys., 2016, 18, 12662-12674.

41 A. M. Arangio, J. H. Slade, T. Berkemeier, U. Pöschl, D. A. Knopf and M. Shiraiwa, J. Phys. Chem. A, 2015, 119, 4533-4544.

42 W. Scheider, J. Phys. Chem., 1972, 76, 349-361.

43 L. J. Lapidus, W. A. Eaton and J. Hofrichter, Proc. Natl. Acad. Sci. U. S. A., 2000, 97, 7220-7225.

44 B. Petersen, T. N. Petersen, P. Andersen, M. Nielsen and C. Lundegaard, BMC Struct. Biol., 2009, 9, 1.

45 J. M. Souza, G. Peluffo and R. Radi, Free Radical Biol. Med., 2008, 45, 357-366.

46 Y. J. Zhang, Y. F. Xu, X. Q. Chen, X. C. Wang and J.-Z. Wang, FEBS Lett., 2005, 579, 2421-2427.

47 R. Radi, Proc. Natl. Acad. Sci. U. S. A., 2004, 101, 4003-4008. 